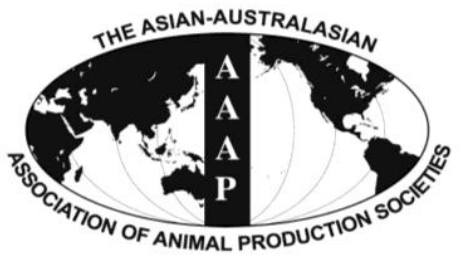

Asian Australas. J. Anim. Sci.

Vol. 26, No. 7 : 1012-1020 July 2013

http://dx.doi.org/10.5713/ajas.2012.12722

www.ajas.info

pISSN 1011-2367 elSSN 1976-5517

\title{
Effects of Dietary Thiazolidinedione Supplementation on Growth Performance, Intramuscular Fat and Related Genes mRNA Abundance in the Longissimus Dorsi Muscle of Finishing Pigs
}

\author{
X. Chen, Y. Feng, W. J. Yang, G. Shu, Q. Y. Jiang, and X. Q. Wang* \\ Guangdong Provincial Key Laboratory of Agro-Animal Genomics and Molecular Breeding, \\ Department of Animal Science, South China Agricultural University, Guangzhou, 510642, China
}

\begin{abstract}
The objective of this study was to investigate the effect of dietary supplementation with thiazolidinedione (TZD) on growth performance and meat quality of finishing pigs. In Experiment 1, 80 castrated finishing pigs (Large White $\times$ Landrace, BW = $54.34 \mathrm{~kg}$ ) were randomly assigned to 2 treatments with 5 replicates of 8 pigs each. The experimental pigs in the 2 groups were respectively fed with a diet with or without a TZD supplementation $(15 \mathrm{mg} / \mathrm{kg}$ ). In Experiment 2, 80 castrated finishing pigs (Large White $\times$ Landrace, $\mathrm{BW}=71.46 \mathrm{~kg}$ ) were divided into 2 treatments as designed in Experiment 1 , moreover, carcass evaluations were performed. The results from Experiment 1 showed that TZD supplementation could significantly decreased the average daily feed intake (ADFI) $(\mathrm{p}<0.05)$ during 0 to $28 \mathrm{~d}$, without impairing the average daily gain (ADG) $(\mathrm{p}>0.05)$. In Experiment 2 , the ADG was significantly increased by TZD supplementation during 14 to $28 \mathrm{~d}$ and 0 to $28 \mathrm{~d}(\mathrm{p}<0.05)$ and the feed:gain ratio (F:G) was significantly decreased by TZD supplementation during 0 to $28 \mathrm{~d}$ ( $\mathrm{p}<0.05$ ). Compared with the control group, TZD group had significantly higher serum triglyceride (TG) concentration at $28 \mathrm{~h}$ and serum high-density lipoprotein (HDL) levels at $14 \mathrm{~d}(\mathrm{p}<0.05)$. Moreover, there was an apparent improvement in the marbling score $(\mathrm{p}<0.10)$ and intramuscular fat (IMF) content $(\mathrm{p}<0.10)$ of the longissimus dorsi muscle in pigs treated by TZD supplementation. Real-time RT-PCR analyses demonstrated that pigs of TZD group had higher mRNA abundance of PPAR $\gamma$ coactivator 1 (PGC-1) $(\mathrm{p}<0.05)$ and fatty acid-binding protein 3 (FABP3) $(\mathrm{p}<0.05)$ than pigs of control group. Taken together, these results suggested that dietary TZD supplementation could improve growth performance and increase the IMF content of finishing pigs through regulating the serum parameters and genes mRNA abundance involved in fat metabolism. (Key Words: Thiazolidinedione, Finishing Pig, Growth Performance, Marbling Score, Intramuscular Fat)
\end{abstract}

\section{INTRODUCTION}

As living standards improve, people are more demanding for high-quality food. Importantly, intramuscular fat (IMF) is a major determinant of meat quality (Li et al., 2011a). The sensory traits of meat products are indeed influenced by the amount of intramuscular fat (Hovenier et al., 1993). However, selection for leanness over the last 21 years in swine has decreased intramuscular fat and adversely influenced pork flavor and color (Schwab et al., 2006). Recently, intramuscular adipose tissue has attracted more attentions of the researchers, in attempt to maintain or improve the meat quality, by the high demand for the marbling fat (Gerbens et

\footnotetext{
* Corresponding Author: X. Q. Wang. Tel: +86-020-38295462, Fax: +86-020-38295462, E-mail: xqwang@ scau.edu.cn Submitted Dec. 31, 2012; Accepted Feb. 1, 2013; Revised Mar. 26, 2013
}

al., 2000; Cánovas et al., 2009; Cordero et al., 2010).

Thiazolidinediones (TZD) are a class of pharmaceutical agents currently used in the treatment of type- 2 diabetes mellitus; they are also known as adipogenic compounds (Fürrnsinn and Waldhausl, 2002). TZD are high-affinity ligands for peroxisome proliferator-activated receptor gamma (PPAR $\gamma$ ) (Lehmann et al., 1995), the critical factor for adipocyte differentiation (Chawla et al., 1994). It has been reported that TZD has physiologically relevant effects on the adipose tissue and the potential to modify intramuscular or marbling adipogenesis (Poulos and Hausman 2006; George et al., 2012). In vitro experiment, MacKellar et al. (2009) has found TZD could lead to more adipocytes and larger cell size in adipose tissue of Zucker rat. The findings of Bouraoui et al. (2011) showed the simultaneous presence of TZD and insulin significantly increased the content of triglycerides in rainbow trout 
adipocyte cells. In vivo experiment, increased intramuscular lipid accumulation has been observed in TZD treated rodents and humans (Mayerson et al., 2002; Muurling et al., 2003; Lessard et al., 2004). However, limited research has investigated the effect of TZD in meat animals, such as pig.

Several genes expressed in the muscle may be involved in the function of TZD, including PPAR $\gamma$ coactivator 1 (PGC-1), glucose transporter 4 (GLUT4) and fatty acidbinding protein 3 (FABP3) (Wu et al., 2010; Li et al., 2011b). PGC-1 is a transcriptional co-activator of PPAR $\gamma$, its mRNA expression level can evaluate the effect of TZD as an agonist (Hondares et al., 2006). GLUT4 plays an important role in maintaining glucose homeostasis in mammals and mediating insulin-stimulated glucose uptake in adipocytes and muscle (Abel et al., 2001; Yang et al., 2011). It was found that activation of PPAR $\gamma$ in fibroblasts can stimulate the synthesis of GLUT4 of adipocytic cells (Wu et al., 1998). Functionally, FABPs are intracellular proteins that transport fatty acids from the cell membrane to sites of fatty acid oxidation or triacylglycerol synthesis. Previously, genetic variants of both heart $(\mathrm{H})$ and adipocyte (A) fatty acid-binding protein (FABP) genes (FABP3 and FABP4) were shown to be associated with IMF content, back fat thickness, and growth (Gerbens et al., 1999). We hypothesized that dietary TZD supplementation could increase the marbling fat content and improve the meat quality in finishing pigs, and the expression of the foregoing genes might be modified by TZD.

Presently, few studies have considered TZD as a dietary supplement. The main objective of the current experiment was to investigate the effects of TZD supplementation on growth performance, serum parameters and intramuscular fat of finishing pigs.

\section{MATERIALS AND METHODS}

\section{Materials}

Thiazolidinedione (TZD) was provided by Beijing Jia Rui Period Technological Co., Ltd (China), TZD's purity was $99.62 \%$.

\section{Animals and diets}

In Experiment 1, a total of 80 castrated male pigs (Large White $\times$ Landrace, $\mathrm{BW}=54.34 \pm 0.22 \mathrm{~kg}$ ) were randomly divided into two treatments. Each treatment had 5 replicates, and 8 pigs each replicate. The initial body weights were not significantly different between two treatments. The animals in the control group were fed with a basic diet, whereas those in the test group were fed with a basic diet supplemented with $15 \mathrm{mg} / \mathrm{kg}$ TZD. In Experiment 2, 80 pigs (Large White $\times$ Landrace, $\mathrm{BW}=71.46 \pm 1.18 \mathrm{~kg}$ ) were assigned to the two groups as described in Experiment 1, but there were slaughter trials for experiment 2 to measure carcass and meat quality.

\section{Feeding and management}

Experiment 1 (from November 12, 2008, to December 20, 2008) and Experiment 2 (from May 5, 2009, to July 14, 2009) were both conducted on the livestock farm of South China Agriculture University (Zeng cheng, Guangzhou, China). The adaptation period lasted for $1 \mathrm{wk}$, and the formal feeding period lasted for 4 wks. The composition of the basic diet is shown in Table 1. The diet and water were offered ad libitum. The temperature of the animal house was maintained at $25^{\circ} \mathrm{C}$. This study was approved by the South China Agricultural University Animal Care Committee.

\section{Growth performance evaluation}

All of the trial pigs were weighed on the day when the experiment started and, subsequently, once every two weeks. The feed consumption was measured per week. The average daily gain (ADG), average daily feed intake (ADFI) and feed: gain $(F: G)$ ratio were determined every two weeks.

\section{Carcass and meat quality evaluation}

In Experiment 2, one pig from each replicate was selected to determine the slaughter trial. The carcass characteristics were evaluated by following the Chinese Agriculture Industry Standard NY-T825-2004 (the standard for the detection of the carcass performance of lean pigs) and the procedures of Yang et al. (2005).

The meat quality traits of longissimus dorsi muscle were analyzed by following the Chinese Agriculture

Table 1. The ingredients composition and nutritional levels of the basic diet

\begin{tabular}{lcc}
\hline Ingredients \% & Exp. 1 (50-70 kg) & Exp. 2 (70-90 kg) \\
\hline Corn & 68 & 68 \\
Soybean meal & 23 & 20 \\
Wheat bran & 0 & 8 \\
Apple meal & 5 & 0 \\
Premix ${ }^{1}$ & 4 & 4 \\
Nutritional levels & & \\
$\quad$ DE MJ/kg & 13.31 & 13.14 \\
CP $(\%)$ & 15.56 & 15.16 \\
Ca (\%) & 0.70 & 0.68 \\
P $(\%)$ & 0.47 & 0.52 \\
Lys $(\%)$ & 0.81 & 0.76 \\
Met+cys $(\%)$ & 0.49 & 0.47 \\
\hline
\end{tabular}

${ }^{1}$ Mineral and vitamin premix provided are as follows per kilogram of diet: Vitamin A 3,600 IU, Vitamin $D_{3} 680 \mathrm{IU}$, Vitamin E $3 \mathrm{mg}$, Vitamin $\mathrm{K}_{3}$ $0.52 \mathrm{mg}$, Vitamin $\mathrm{B}_{1} 1 \mathrm{mg}$, Vitamin $\mathrm{B}_{2} 2 \mathrm{mg}$, Vitamin $\mathrm{B}_{6} 1 \mathrm{mg}$, Vitamin $\mathrm{B}_{12} 2 \mathrm{mg}$, Niacin $7 \mathrm{mg}$, D-calcium pantothenate $7 \mathrm{mg}$, Choline chloride $0.3 \mathrm{~g}$, Folic acid $0.3 \mathrm{mg}$, Copper $12 \mathrm{mg}$, Iron $60 \mathrm{mg}$, Manganese $8 \mathrm{mg}$, Zinc $48 \mathrm{mg}$. 
Industry Standard NY-T821-2004 (the standard for the detection of pigs' meat quality) and the procedures of Li et al. (2007).

The color coordinates was calculated with a Minolta spectrophotometer (MINOLTA, CR-400) (lightness, L*; redness, $\mathrm{a}^{*}$; yellowness, $\mathrm{b}^{*}$ ). The $\mathrm{pH}$ was measured using a combined glass electrode connected to a portable $\mathrm{pH}$ meter (DLETA 320, Mettler-Toledo, Shang hai, China). Samples of the longissimus dorsi muscle were obtained for IMF content evaluation according to Hovenier et al. (1992). Intramuscular fat content was determined using the Soxhlet petroleum-ether extraction method and the results were expressed in a percentage of raw meat weight.

\section{Determination of serum biochemical indices}

On d 14 and 28, blood samples were obtained through the precaval vein from 2 selected pigs of average weight from each replicate (Tang et al., 2005). Serum was collected at $3,000 \mathrm{r} / \mathrm{min}$ for $10 \mathrm{~min}$ and stored at $-20^{\circ} \mathrm{C}$. The concentrations of glucose (GLU), triglyceride (TG), total protein (TP), serum urea nitrogen (SUN) and high density lipoprotein (HDL) were measured with a commercial assay kit (Nanjing Jianchen Biological Product Co. Ltd., China) according to the manufacturer's introductions.

\section{RNA extraction and cDNA synthesis}

Total RNA was extracted from the longissimus dorsi muscle tissue using TRIZOL reagent (Invitrogen, Carlsbad, CA, USA) and treated with DNase I (Invitrogen) according to the manufacturer's instructions. The RNA quality was checked using $1 \%$ agarose gel electrophoresis followed by staining with $10 \mu \mathrm{g} / \mathrm{ml}$ ethidium bromide. The RNA had an $\mathrm{OD}_{260}: \mathrm{OD}_{280}$ ratio between 1.8 and 2.0.

The synthesis of the first-strand cDNA was performed for $1 \mathrm{~h}$ at $37^{\circ} \mathrm{C}$ in a reaction volume of $20 \mu \mathrm{l}$ containing 2 $\mu \mathrm{g}$ of purified total RNA, $5 \mu \mathrm{mol} / \mathrm{L}$ oligo dT (18), $4 \mu \mathrm{l}$ $5 \times \mathrm{RT}$ buffer, $1 \mathrm{mmol} / \mathrm{L}$ dNTP, $20 \mathrm{U}$ RNase inhibitor (Takara, Dalian) and $200 \mathrm{U}$ reverse transcriptase (MMLV, Promega). The synthesized first-strand cDNA samples were diluted by the addition of ultra-purified water (Geng et al., 2011).

\section{Quantification of mRNA by real-time PCR analysis}

Gene expression at the mRNA level was analyzed by quantitative real-time PCR with specific primers designed by Premier5.0 (Table 2). The housekeeping gene GAPDH was used as an internal control. PCR was performed in a 20 $\mu \mathrm{l}$ reaction containing $10 \mu \mathrm{l} 2 \times \mathrm{SYBR}$ Green Master Mix, 1 $\mu \mathrm{l}$ cDNA template, $1 \mu \mathrm{l} 10 \mu \mathrm{mol}$ primer and $0.4 \mu \mathrm{l}$ ROX. After a single pre-denaturation cycle at $95^{\circ} \mathrm{C}$ for $1 \mathrm{~min}$, the amplification was performed for 35 cycles $\left(95^{\circ} \mathrm{C}\right.$ for $15 \mathrm{~s}$, $58^{\circ} \mathrm{C}$ for $15 \mathrm{~s}, 72^{\circ} \mathrm{C}$ for $40 \mathrm{~s}$ ) with a melting curve program $\left(95^{\circ} \mathrm{C}\right.$ for $1 \mathrm{~min}, 58^{\circ} \mathrm{C} / 62^{\circ} \mathrm{C}$ for $30 \mathrm{~s}, 95^{\circ} \mathrm{C}$ for $30 \mathrm{~s}$ ). Amplification and melt-curve analysis were performed in Mx3005P (Agilent Stratagene, USA). The relative mRNA abundance of the target genes were evaluated as $\mathrm{R}=$ $2^{-(\mathrm{Ct}(\mathrm{GAPDH})-\mathrm{Ct}(\text { target gene }))}$

\section{Statistical analysis}

All data were presented as means \pm SE and were analyzed by independent-samples T-tests using SAS (SAS Institute, 2004). Differences between groups were considered statistically significant if $\mathrm{p}<0.05$, and there was tendency toward statistical significance if $\mathrm{p}<0.10$.

\section{RESULTS}

\section{Effects of TZD on growth performance}

Experiment 1 (the early stage of the finishing pigs): Compared with the control group, the addition of TZD slightly decreased the ADFI by $6.65 \%$ and $3.00 \%(p<0.10)$ during 0 to $14 \mathrm{~d}$ and 15 to $28 \mathrm{~d}$, respectively (Table 3 ), and TZD supplementation significantly decreased the ADFI $(\mathrm{p}<0.05)$ of TZD group during 0 to $28 \mathrm{~d}$. TZD also decreased the $F: G$ ratio by $5.13 \%$ during 0 to $28 \mathrm{~d}$ ( $p>0.05$ ), whereas the ADG was not influenced by TZD supplementation $(\mathrm{p}>0.05)$.

Experiment 2 (the late stage of the finishing pigs): Compared with the control group, TZD supplementation resulted in an significant increase in the ADG of TZD group during 14 to $28 \mathrm{~d}$ and 0 to $28 \mathrm{~d}(\mathrm{p}<0.05)$, moreover, TZD reduced the $\mathrm{F}: \mathrm{G}$ ratio by $4.00 \%$ during 0 to $28 \mathrm{~d}(\mathrm{p}<0.05)$. There was no difference in the ADFI between the control

Table 2. Parameters of primer pairs for PGC-1, GLUT4, FABP3 and GAPDH

\begin{tabular}{|c|c|c|c|c|}
\hline$\overline{\text { Genes }}$ & Localization & Primer sequence & Product (bp) & $\operatorname{Tm}\left({ }^{\circ} \mathrm{C}\right)$ \\
\hline \multirow[t]{2}{*}{$\overline{\text { PGC-1 }}$} & $1,004-1,021$ & 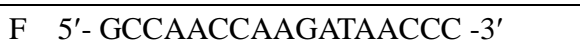 & 107 & 62 \\
\hline & $1,093-1,110$ & $\mathrm{R}$ 5'- GTCCCCGAAGACTCACT -3' & & \\
\hline \multirow[t]{2}{*}{ GLUT4 } & $1,341-1,361$ & F 5'- TGAGTTTCCAGTATGTTGCG-3' & 107 & 58 \\
\hline & $1,447-1,467$ & R 5'-GGTTTCAGGCACTTTTAGGA -3' & & \\
\hline \multirow[t]{2}{*}{ FABP3 } & $209-229$ & F 5 '- AGCACCTTCAAGAGCACAGA-3' & 147 & 62 \\
\hline & $320-340$ & 5 '-CAAGTTTGCCTCCATCCAGT-3' & & \\
\hline \multirow[t]{2}{*}{ GAPDH } & $350-369$ & F 5'-GGTCGGAGTGAACGGATTTG -3' & 170 & 58 \\
\hline & $500-519$ & R 5'-CCTTGACTGTGCCGTGGAAT-3' & & \\
\hline
\end{tabular}


Table 3. The effect of TZD supplementation on growth performance of finishing pigs

\begin{tabular}{|c|c|c|c|c|c|}
\hline \multirow{2}{*}{ Item } & \multirow{2}{*}{ Period } & \multicolumn{2}{|c|}{ Exp.1 } & \multicolumn{2}{|c|}{ Exp.2 } \\
\hline & & Control & TZD & Control & TZD \\
\hline \multirow{3}{*}{$\begin{array}{l}\text { ADFI } \\
\text { (g/pig/d) }\end{array}$} & $0-14 \mathrm{~d}$ & $2,483.3 \pm 108.0$ & $2,318.3 \pm 15.0$ & $2,268.5 \pm 57.4$ & $2,252.8 \pm 14.0$ \\
\hline & $15-28 d$ & $2,554.5 \pm 64.0$ & $2,477.8 \pm 30.7$ & $2,619.3 \pm 93.1$ & $2,680.5 \pm 54.0$ \\
\hline & $0-28 \mathrm{~d}$ & $2,518.9 \pm 27.1 *$ & $2,398.0 \pm 8.7$ & $2,443.9 \pm 59.8$ & $2,466.7 \pm 27.3$ \\
\hline \multirow{3}{*}{$\begin{array}{l}\text { ADG } \\
\text { (g/pig/d) }\end{array}$} & $0-14 \mathrm{~d}$ & $748.9 \pm 34.6$ & $726.8 \pm 32.2$ & $687.3 \pm 21.7$ & $693.6 \pm 13.4$ \\
\hline & $15-28 \mathrm{~d}$ & $694.5 \pm 41.4$ & $715.9 \pm 17.8$ & $796.2 \pm 17.3$ & $871.9 \pm 18.3 *$ \\
\hline & $0-28 \mathrm{~d}$ & $721.7 \pm 17.7$ & $721.4 \pm 24.9$ & $752.4 \pm 10.6$ & $791.0 \pm 12.9 *$ \\
\hline \multirow[t]{3}{*}{$\mathrm{F}: \mathrm{G}$} & $0-14 \mathrm{~d}$ & $3.33 \pm 0.18$ & $3.20 \pm 0.16$ & $3.27 \pm 0.11$ & $3.26 \pm 0.09$ \\
\hline & $15-28 d$ & $3.71 \pm 0.25$ & $3.46 \pm 0.05$ & $3.30 \pm 0.11$ & $3.09 \pm 0.06$ \\
\hline & $0-28 \mathrm{~d}$ & $3.51 \pm 0.06$ & $3.33 \pm 0.10$ & $3.25 \pm 0.04$ & $3.12 \pm 0.02 *$ \\
\hline
\end{tabular}

Data are expressed as means \pm SE, $n=5$. In Exp. 1 or Exp. 2, values with * within same line were significantly different $(\mathrm{p}<0.05)$, values with different letters within same line was tendency toward statistical significance $(\mathrm{p}<0.10)$.

and TZD groups $(\mathrm{p}>0.05)$.

\section{Effects of TZD on carcass performance and meat quality}

There were little differences in the measured carcass traits between the control and TZD groups (Table 4), except that pigs in the TZD group had a $5.68 \%$ lower lean percentage than that of pigs in the control group, but without significant difference $(p>0.05)$. In the context of the meat quality traits, TZD supplementation had no effect on water loss $(\mathrm{p}>0.05)$ and $\mathrm{pH}$ values $(\mathrm{p}>0.05)$. Pigs fed with TZD had a $6.42 \%$ higher $a^{*}$ value $(p<0.10)$ than that of those fed with the control diet. The marbling score was increased by $32.18 \%$ by TZD supplementation $(\mathrm{p}<0.10)$, and the IMF content was increased by $16.43 \%(p<0.10)$, compared with the control group.

\section{Effects of TZD on serum biochemical indices}

In Experiment 2, compared with the control group, TZD

Table 4. The effect of TZD supplementation on carcass performance and meat quality $(n=5)$

\begin{tabular}{lcc}
\hline Item & Control & TZD \\
\hline Dressing percentage $(\%)$ & $72.47 \pm 0.74$ & $73.35 \pm 0.33$ \\
Lean percentage $(\%)$ & $59.32 \pm 1.35$ & $55.95 \pm 1.89$ \\
Backfat thickness $(\mathrm{mm})$ & $27.42 \pm 3.43$ & $26.03 \pm 2.75$ \\
Eye muscle area $\left(\mathrm{mm}^{2}\right)$ & $46.68 \pm 3.86$ & $45.05 \pm 5.36$ \\
$\mathrm{~L}^{*}$ & $45.09 \pm 1.72$ & $42.53 \pm 2.79$ \\
$\mathrm{a}^{*}$ & $13.85 \pm 0.32^{\mathrm{b}}$ & $14.74 \pm 0.42^{\mathrm{a}}$ \\
$\mathrm{b}^{*}$ & $0.20 \pm 0.03$ & $0.18 \pm 0.02$ \\
$\mathrm{Water} \mathrm{loss}(\%)^{\mathrm{pH}}{ }_{45 \text { min }}$ & $5.53 \pm 0.51$ & $4.92 \pm 0.51$ \\
pH & $6.09 \pm 0.09$ & $6.23 \pm 0.14$ \\
Marbling score & $5.51 \pm 0.04$ & $5.44 \pm 0.06$ \\
Intramuscular fat $(\%)$ & $1.74 \pm 0.12^{\mathrm{b}}$ & $2.30 \pm 0.25^{\mathrm{a}}$ \\
\hline
\end{tabular}

Data are expressed as means \pm SE, $n=5$.

Values with * within same line were significantly different $(\mathrm{p}<0.05)$ values with different letters within same linw was tendency toward statistical significance $(\mathrm{p}<0.10)$. supplementation tended to increase the serum TG concentration by $11.11 \%$ on $\mathrm{d} 14(\mathrm{p}<0.10)$ and significantly increased the serum TG concentration by $17.24 \%$ on $\mathrm{d} 28$ $(\mathrm{p}<0.05)$ (Table 5). Moreover, pigs fed with TZD had higher levels of serum HDL than pigs fed with the control diet on $\mathrm{d}$ 28 ( $\mathrm{p}<0.05)$. Otherwise, the serum TP concentration was significantly lower in TZD group than the control group $(p<0.05)$. However, TZD treatment had no effect on the GLU and SUN concentration ( $p>0.05)$.

\section{Effects of TZD on relative mRNA abundance}

The adjusted mRNA abundance of PGC-1 was significantly higher in the longissimus dorsi muscle of pigs fed with TZD than that of control animals $(\mathrm{p}<0.05)$ (Table 6). TZD supplementation resulted in an up-regulation of FABP3 expression (a $65.12 \%$ increase in mRNA abundance, $\mathrm{p}<0.10)$. There was no difference in the mRNA abundance of GLUT4 between the control group and TZD group $(\mathrm{p}>0.05)$.

\section{DISCUSSIONS}

Nutrition redistribution agents have received a lot of attentions in recent years because their great ability to improve human health and animal production. Conjugated linoleic acid (CLA) and Arginine (Arg) are two typical agents of this kind commonly used in the livestock industry. Previous studies have reported CLA can decrease the body fat mass (West et al., 1998; Sisk et al. 2001; Meadus et al., 2002) and increase the lean body mass (House et al., 2005; Gaullier et al., 2007) through suppressing the expression of PPAR $\gamma$ (Kang et al., 2003), inhibiting the convertion of preadipocyte into adipocyte (Miller et al., 2008). Arg has also been reported to have the capacity to decrease the body fat accretion and enhance the muscle gain (He et al., 2009; Tan et al., 2009), which involves multiple NO-dependent pathways (Jobgen et al., 2006), and also correlated to the functions of PPAR $\gamma$ (Vasilijevic et al., 2010). These studies 
Table 5. The effect of TZD supplementation on index of blood serum of finishing pigs

\begin{tabular}{|c|c|c|c|c|c|}
\hline \multirow{2}{*}{ Item } & \multirow{2}{*}{ Period } & \multicolumn{2}{|c|}{ Exp. 1} & \multicolumn{2}{|c|}{ Exp. 2} \\
\hline & & Control & TZD & Control & TZD \\
\hline \multirow{2}{*}{$\begin{array}{l}\text { GLU } \\
(\mathrm{mmol} / \mathrm{L})\end{array}$} & $14 \mathrm{~d}$ & $4.54 \pm 0.45$ & $4.93 \pm 0.20$ & $3.31 \pm 0.12$ & $3.30 \pm 0.18$ \\
\hline & $28 \mathrm{~d}$ & $4.13 \pm 0.20$ & $4.24 \pm 0.45$ & $3.20 \pm 0.13$ & $3.19 \pm 0.18$ \\
\hline \multirow{2}{*}{$\begin{array}{l}\text { SUN } \\
(\mathrm{mmol} / \mathrm{L})\end{array}$} & $14 \mathrm{~d}$ & $6.56 \pm 1.05$ & $4.30 \pm 0.52$ & $5.36 \pm 0.24$ & $5.11 \pm 0.19$ \\
\hline & $28 \mathrm{~d}$ & $6.38 \pm 0.97$ & $4.38 \pm 0.44$ & $6.05 \pm 0.29$ & $6.43 \pm 0.33$ \\
\hline \multirow{2}{*}{$\begin{array}{l}\text { TP } \\
(\mathrm{g} / \mathrm{L})\end{array}$} & $14 \mathrm{~d}$ & $70.25 \pm 1.71$ & $64.96 \pm 1.09$ & $86.79 \pm 2.50 *$ & $77.74 \pm 1.87$ \\
\hline & $28 \mathrm{~d}$ & $72.37 \pm 2.37$ & $67.87 \pm 3.82$ & $77.44 \pm 2.55$ & $74.43 \pm 0.69$ \\
\hline \multirow{2}{*}{$\begin{array}{l}\text { TG } \\
\qquad(\mathrm{mmol} / \mathrm{L})\end{array}$} & $14 \mathrm{~d}$ & $0.32 \pm 0.03$ & $0.32 \pm 0.04$ & $0.54 \pm 0.03^{b}$ & $0.60 \pm 0.02^{\mathrm{a}}$ \\
\hline & $28 \mathrm{~d}$ & $0.36 \pm 0.03$ & $0.32 \pm 0.02$ & $0.58 \pm 0.03$ & $0.68 \pm 0.03 *$ \\
\hline \multirow{2}{*}{$\begin{array}{l}\mathrm{HDL} \\
(\mathrm{mmol} / \mathrm{L})\end{array}$} & $14 \mathrm{~d}$ & $\mathrm{ND}^{1}$ & ND & $0.71 \pm 0.04$ & $0.83 \pm 0.02 *$ \\
\hline & $28 \mathrm{~d}$ & ND & ND & $0.72 \pm 0.05$ & $0.76 \pm 0.04$ \\
\hline
\end{tabular}

Data are expressed as means \pm SE, $n=10$. In Exp. 1 or Exp. 2, values with * within same line were significantly different $(p<0.05)$, values with different letters within same line was tendency toward statistical significance $(\mathrm{p}<0.10)$.

${ }^{1} \mathrm{ND}=$ Not detected.

suggested the influence of nutrition redistribution agents mainly focused on the muscle and adipose tissues, and generally involved in PPAR $\gamma$ pathways. In the present study, TZD played a crucial role as CLA and Arg in nutritional distribution, as well as in PPAR $\gamma$ pathways related genes expression.

In Experiment 1, dietary TZD supplementation significantly decreased the ADFI without affecting the ADG, whereas in Experiment 2, TZD increased the ADG and lowered the F:G ratio. The results from the Experiment 2 agreed with the findings of Miyazaki et al. (2002), which demonstrated that type-2 diabetic patients exhibit a significant increase in the body weight after treatment with dietary pioglitazone for $16 \mathrm{wks}$. The explanation for this could be that TZD is able to shift the energy balance toward storage, leading to an increase in the whole-body adiposity and the number of small adipocytes (Souza et al., 2001). Combining the results that showed lean percentage of TZDtreated pigs was lower in numerical value; it was presumed the increased ADG in TZD group was mainly due to more adipose deposition in the body. Otherwise, the influence of TZD supplementation on growth performance differed

Table 6. mRNA abundance of related genes in the longissimus dorsi muscle ${ }^{1,2}$

\begin{tabular}{llc}
\hline Gene & \multicolumn{1}{c}{ Control } & TZD \\
\hline PGC-1 & $0.0061 \pm 0.0006$ & $0.0237 \pm 0.0070^{*}$ \\
FABP3 & $0.0860 \pm 0.0087^{\mathrm{b}}$ & $0.1420 \pm 0.0356^{\mathrm{a}}$ \\
GLUT4 & $0.0711 \pm 0.0157$ & $0.0753 \pm 0.0147$ \\
\hline
\end{tabular}

Data are expressed as means \pm SE, $n=5$.

Values with $*$ within same line were significantly different $(\mathrm{p}<0.05)$, values followed by different letters is considered there was tendency toward statistical significance $(\mathrm{p}<0.10)$.

${ }^{1}$ mRNA abundance for each target gene relative to glyceraldehyde- 3phosphate dehydrogenase expression.

${ }^{2}$ PGC-1 = PPAR $\gamma$ coactivator 1 ; FABP3 = Fatty acid-binding protein 3; GLUT4 = Glucose transporter 4 . between pigs at different ages. This implied that the effect of TZD was dependent on the growth phase, and the ADG and $F: G$ ratio was more prone to be impacted by TZD in the late phase of finishing pigs.

In the current work, carcass parameters were not affected by TZD supplementation. However, the observed trends towards an effect of TZD on marbling and IMF content in the longissimus dorsi muscle were of high magnitude. The results agreed with the previous studies which observed that the intramuscular lipid accumulation was increased in TZD treated rodents (Muurling et al., 2003; Todd et al., 2007; Chabowski et al., 2011). Importantly, research in pigs has demonstrated that TZD is able to increase the lipid accretion in the muscle (Hausman et al., 2008). This might be attributed to the great ability of TZD on adipose differentiation through activating PPAR $\gamma$ (Acharya and Falik, 2009), as Teboul (1995) has reported the potential of TZD to trans-differentiate $\mathrm{C} 2 \mathrm{C} 12 \mathrm{~N}$ myoblasts into adipoblasts. The results suggested TZD supplementation has the ability to impact the adipose tissue in the skeletal muscle of pigs. Additionally, TZD increased $a^{*}$ value by $6.42 \%$, suggesting that the meat products of the TZD group appeared to be redder and more favorable in color.

In Experiment 1, no effect of TZD on serum parameters was found. In Experiment 2, the serum TG concentration was increased both on $\mathrm{d} 14$ and $\mathrm{d} 28$ by TZD supplementation, and the level of serum HDL on d 14 was also higher in TZD treated pigs $(\mathrm{p}<0.05)$, indicating the lipid utilization was increased, otherwise, fat metabolism in vivo was improved and shifted toward fatty deposition. This could be correlated with the results that pigs fed with TZD had a higher IMF content and lower lean percentage, which were caused by elevated fatty deposition. There was little difference in the serum GLU concentration between the two groups. However, clinical study demonstrated that diabetic 
patients treated with TZD have a lower plasma glucose concentration and higher level of GLUT4 expression (Miyazaki et al., 2002). An explanation for this difference might be that TZD influenced the serum glucose concentration only when glucose metabolism in vivo is abnormal, and in our study all the trial animals were in healthy situation. These results suggested that TZD had a great effect on serum parameters related to fat metabolism.

PPAR $\gamma$ is predominant in adipocytes differentiation and lipid storage (Chinetti et al., 2000; Singh et al., 2007), and the adipogenesis begins with the activation of PPAR $\gamma$ in the presence of TZD (Wu et al., 1996). However, PPAR $\gamma$ is primarily expressed in adipose tissue (Chinetti et al., 2000), therefore, we selected PGC-1, the co-activator of PPAR $\gamma$, as a mark gene in the experiment. The mRNA abundance of PGC-1 in the longissimus dorsi muscle was significantly increased by TZD supplementation, compared with the control group. The result was consistent with the hypothesis; TZD influenced the fatty deposition and serum parameters through activating the critical gene involved in fat metabolism. Moreover, TZD supplementation increased the mRNA abundance of FABP3 mRNA by $65.12 \%$ above that of the control group, indicating an up-regulated transport and accretion of fatty acids in the muscle of TZDfed animals. This is consistent with the findings of Hallakou (1997) showing that a TZD treatment of the obese Zucker rat induced a marked increase in weight gain, and stimulated the expression of genes necessary for lipid metabolism. Moreover, it has been reported the expression of FABP3 was positively correlated with the IMF content (Cho et al., 2011), thus the increased IMF levels in the TZD group could be associated with the up-regulated expression of FABP3. There was no difference in the mRNA abundance of GLUT4 between the control and TZD groups, which was inconsistent with the findings of other researches (Hallakou et al., 1997; Miyazaki et al., 2002). It suggested TZD had no effect on glucose utilization when it was supplemented for healthy animals.

In summary, like other nutrition redistribution agents (Liu et al., 2012), TZD exhibited its effect through involving PPAR $\gamma$ or the related genes, targeting the adipose tissue. Moreover, TZD has the potential to be a new nutrition redistribution additive used to improve meat quality because TZD could increase marbling score and IMF content in meat animals, which has also been reported in researches about Arg, a above mentioned nutrition redistributor (Tan et al., 2009; Ma et al., 2010; Tan et al., 2011; Yao et al., 2012). As a PPAR $\gamma$ agonist, it has been reported TZD could activate PPAR $\gamma$ in adipocytes (Reginato et al., 1998). In the present study, TZD could activate PGC1 , and up-regulate its expression in muscle cells or adipocytes in muscle adipose tissue of the TZD-treated pigs, subsequently the expression of the downstream genes such as FABP3, which involved in PPAR $\gamma$ pathway, will be increased to enlarge the effect of TZD supplementation. In the physiological levels, it was hypothesized the upregulated expressions of these genes promoted the accretion of fatty acids in the muscle, increased serum TG and HDL concentrations, thus inducing a more active fat metabolism in vivo and the tendency towards adipose deposition. Otherwise, insulin sensitivity might be improved by the activation of PPAR $\gamma$, which has been reported in rodents and humans, through a combination of metabolic actions, which promoted the deposition of the nutrients and partitioning of lipid stores (Tontonoz and Spiegelman, 2008). Finally, these changes contribute to the improvement of growth performance and the elevated IMF content, which might be correlated to the increased adipose deposition in the whole body.

\section{CONCLUSION}

Dietary TZD supplementation could increase the ADG and decrease the F:G ratio, and elevate the serum TG and HDL levels, importantly, had a positive effect on marbling score and IMF content, which was related with PGC-1 and FABP3, the genes involved in fat metabolism. In addition, the effects of TZD was significant in the late phase of finishing pigs, but not obvious in the early phase.

\section{ACKNOWLEDGEMENT}

This work was supported by National Major Science Research Program of China (2012CB124704), National 948 Program of China (2011-G35), Special Fund for Public Welfare Industry of China (Agriculture, 201003011), Education Department Key Project of Guangdong Province (2012CXZD0015), and Science and Technology Planning Project of Guangdong Province, China (2012B020305006, 2011B090400190).

\section{REFERENCES}

Abel, E. D., O. Peroni, J. K. Kim, Y. B. Kim, and O. Boss. 2001. Adipose-selective targeting of the GLUT4 gene impairs insulin action in muscle and liver. Nature 409:729-733.

Acharya, D., and R. Falik. 2009. Cardiovascular effects of thiazolidinediones: a review of the literature. South. Med. J. 102:51-56.

Bouraoui, L., L. Cruz-Garcia, J. Gutiérrez, E. Capilla, and I. Navarro. 2012. Regulation of lipoprotein lipase gene expression by insulin and troglitazone in rainbow trout (Oncorhynchus mykiss) adipocyte cells in culture. Comp. Biochem. Physiol-Part A: Mol. Integr. Physiol. 161:83-88.

Cánovas, E., R. Quintanilla, B. Badaoui, C. Porredón, D. Gallardo, R. Pena, I. Díaz, and M. Amills. 2009. Pig HDL-binding protein (HDLBP) genotype is associated with intramuscular fat 
percentage. Livest. Sci. 126:298-301.

Chabowski, A., M. Żendzian-Piotrowska, A. Nawrocki, and J. Górski. 2011. Not only accumulation, but also saturation status of intramuscular lipids is significantly affected by PPAR $\gamma$ activation. Acta. Physiol. 205:145-158.

Chawla, A., E. Schwarz, D. Dimaculangan, and M. Lazar. 1994. Peroxisome proliferator-activated receptor (PPAR) gamma: adipose-predominant expression and induction early in adipocyte differentiation. Endocrinology 135:798-800.

Chinetti, G., J. C. Fruchart, and B. taels. 2000. Peroxisome proliferator-activated receptors (PPARs): nuclear receptors at the crossroads between lipid metabolism and inflammation. Inflamm. Res. 49:497-505.

Cho, K. H., M. J. Kim, G. J. Jeon, and H. Y. Chung. 2011. Association of genetic variants for FABP3 gene with back fat thickness and intramuscular fat content in pig. Mol. Biol. Rep. 38:2161-2166.

Cordero, G., B. Isabel, D. Menoyo, A. Daza, J. Morales, C. Pineiro, and C. J. Lopez-Bote. 2010. Dietary CLA alters intramuscular fat and fatty acid composition of pig skeletal muscle and subcutaneous adipose tissue. Meat. Sci. 85:235-239.

Deng, J. P., F. Yang, Y. L. Yin, Z. Q. Liu, F. Y. Yan, Y. Z. Zhang, and Z. R. Tang. 2010. Effects of digestible lysine levels on growth performance, serum metabolites and carcass composition in barrow. J. Food Agric. Environ. 8:514-518.

Fürrnsinn, C., and W. Waldhausl. 2002. Thiazolidinediones: metabolic actions in vitro. Diabetologia 45:1211-1223.

Gaullier, J. M., J. Halse, H. O. Hoivik, K. Hoye, C. Syvertsen, M. Nurminiemi, C. Hassfeld, A. Einerhand, M. O'Shea, and O. Gudmundsen. 2007. Six months supplementation with conjugated linoleic acid induces regional-specific fat mass decreases in overweight and obese. Br. J. Nutr. 97:550-560.

Gerbens, F., D. Koning, F. Harders, T. Meuwissen, L. Janss, M. Groenen, J. Veerkamp, J. Van. Arendonk, and M. Te. Pas. 2000. The effect of adipocyte and heart fatty acid-binding protein genes on intramuscular fat and backfat content in Meishan crossbred pigs. J. Anim. Sci. 78:552-559.

Gerbens, F., A. Van. Erp, F. Harders, F. Verburg, T. Meuwissen, J. Veerkamp, and Te. Pas. M. 1999. Effect of genetic variants of the heart fatty acid-binding protein gene on intramuscular fat and performance traits in pigs. J. Anim. Sci. 77:846-852.

Geng, M. M., T. J. Li, X. F. Kong, X. Y. Song, W. Y. Chu, R. L. Huang, Y. L. Yin, and G. Y. Wu. 2011. Reduced expression of intestinal $\mathrm{N}$-acetylglutamate synthase in suckling piglets: a novel molecular mechanism for arginine as a nutritionally essential amino acid for neonates. Amino Acids 40:1513-1522.

George, R. B. Jr., B. K. Natasha, F. B. Gary, E. C. Corinne, L. Yiming, M. G. Laura, S. Joselita, P. Limin, P. Francisco, U. Denise, S. Dawn, and E. U. Guillermo. 2012. The effects of thiazolidinediones on human bone marrow stromal cell differentiation in vitro and in thiazolidinedione-treated patients with type 2 diabetes. Transl. Res. In Press. 161:145-155.

Hallakou, S., L. Doare, F. Foufelle, M. Kergoat, M. Guerre-Millo, M. Berthault, I. Dugail, J. Morin, J. Auwerx, and P. Ferre. 1997. Pioglitazone induces in vivo adipocyte differentiation in the obese Zucker fa/fa rat. Diabetes 46:1393-1399.

Hausman G., S. Poulos, T. Pringle, and M. Azain. 2008. The influence of thiazolidinediones on adipogenesis in vitro and in vivo: potential modifiers of intramuscular adipose tissue deposition in meat animals. J. Anim. Sci. 86:236-243.

He, Q., X. Kong, G. Wu, P. Ren, H. Tang, F. Hao, R. Huang, T. Li, B. Tan, and P. Li. 2009. Metabolomic analysis of the response of growing pigs to dietary L-arginine supplementation. Amino Acids 37:199-208.

Hondares, E., O. Mora, P. Yubero, M. R. de la Concepción, R. Iglesias, M. Giralt, and F. Villarroya. 2006. Thiazolidinediones and rexinoids induce peroxisome proliferator-activated receptor-coactivator (PGC)-1 $\alpha$ gene transcription: an autoregulatory loop controls PGC- $1 \alpha$ expression in adipocytes via peroxisome proliferator-activated receptor- $\gamma$ coactivation. Endocrinology 147:2829-2838.

House, R., J. Cassady, E. Eisen, M. McIntosh, and J. Odle. 2005. Conjugated linoleic acid evokes de-lipidation through the regulation of genes controlling lipid metabolism in adipose and liver tissue. Obes. Rev. 6:247-258.

Hovenier, R., E. Kanis, T. Van. Asseldonk, and N. Westerink. 1992. Genetic parameters of pig meat quality traits in a halothane negative population. Livest. Prod. Sci. 32:309-321.

Hovenier, R., E. Kanis, T. Van. Asseldonk, and N. Westerink. 1993. Breeding for pig meat quality in halothane-negative populations a review. Pig News Info. 14:17-25.

Kang, K., W. Liu, J. K. Albright, Y. Park, and M. W. Pariza. 2003. trans-10, cis-12 CLA inhibits differentiation of 3T3-L1 adipocytes and decreases PPAR [gamma] expression. Biochem. Biophys. Res. Commun. 303:795-799.

Jobgen, W. S., S. K. Fried, W. J. Fu, C. J. Meininger, and G. Wu. 2006. Regulatory role for the arginine-nitric oxide pathway in metabolism of energy substrates. J. Nutr. Biochem. 17:571-588.

Lehmann, J. M., L. B. Moore, T. A. Smith-Olive.r, W. O. Wilkison, T. M. Willson, and S. A. Kliewer. 1995. An antidiabetic thiazolidinedione is a high affinity ligand for peroxisome proliferator-activated receptor $\gamma(\operatorname{PPAR} \gamma)$. J. Biol. Chem. 270: 12953-12956.

Lessard, S. J., S. L. L. Giudice, W. Lau, J. J. Reid, N. Turner, M. A. Febbraio, J. A. Hawley, and M. J. Watt. 2004. Rosiglitazone enhances glucose tolerance by mechanisms other than reduction of fatty acid accumulation within skeletal muscle. Endocrinology 145:5665-5670.

Li, F. N., L. L. Li, H. S. Yang, X. X. Yuan, B. Zhang, M. M. Geng, C. W. Xiao, and Y. L. Yin. 2011a. Regulation of soy isoflavones on weight gain and fat percentage: evaluation in a Chinese Guangxi minipig model. Animal 5:1903-1908.

Li, F. N., H. S. Yang, Y. H. Duan, and Y. L. Yin. 2011b. Myostatin regulates preadipocyte differentiation and lipid metabolism of adipocyte via ERK1/2. Cell Biol. Int. 35:1141-1146.

Li, L. L., Z. P. Hou, Y. L. Yin, Y. H. Liu, D. X. Hou, B. Zhang, G. Y. Wu, S. W. Kim, M. Z. Fang, C. B. Yang, X. F. Kong, Z. R. Tang, H. Z. Peng, D. Deng, Z. Y. Deng, M. Y. Xie, H. Xiong, P. Kang, and S. X. Wang. 2007. Intramuscular administration of zinc metallothionein to preslaughter stressed pigs improves anti-oxidative status and pork quality. Asian-Aust. J. Anim. Sci. 20:761-767.

Liu, X. D., X. Wu, Y. L. Yin, Y. Q. Liu, M. M. Geng, H. S. Yang, B. Francois, and G. Y. Wu. 2012. Effects of dietary L-arginine or N-carbamylglutamate supplementation during late gestation of sows on the miR-15b/16, miR-221/222, VEGF and iNOS expression in umbilical vein. Amino Acids. 42:2111-2119. 
Ma, X., Y. Lin, Z. Jiang, C. Zheng, G. Zhou, D. Yu., T. Cao, J. Wang, and. F. Chen. 2010. Dietary arginine supplementation enhances antioxidative capacity and improves meat quality of finishing pigs. Amino Acids 38:95-102.

MacKellar, J., S. W. Cushman, and V. Periwal. 2009. Differential Effects of Thiazolidinediones on Adipocyte Growth and Recruitment in Zucker Fatty Rats. Plos One. 4:e8196.

Mayerson, A. B., R. S. Hundal, S. Dufour, V. Lebon, D. Befroy, G. W. Cline, S. Enocksson, S. E. Inzucchi, G. I. Shulman, and K. F. Petersen. 2002. The effects of rosiglitazone on insulin sensitivity, lipolysis, and hepatic and skeletal muscle triglyceride content in patients with type 2 diabetes. Diabetes 51:797-802.

Meadus, W., R. MacInnis, and M. Dugan. 2002. Prolonged dietary treatment with conjugated linoleic acid stimulates porcine muscle peroxisome proliferator activated receptor gamma and glutamine-fructose aminotransferase gene expression in vivo. $\mathrm{J}$. Mol. Endocrinol. 28:79-86.

Miller, J. R., P. Siripurkpong, J. Hawes, A. Majdalawieh, H. S. Ro, and R. S. McLeod. 2008. The trans-10, cis-12 isomer of conjugated linoleic acid decreases adiponectin assembly by PPARgamma-dependent and PPARgamma-independent mechanisms. J. Lipid Res. 49:550-562.

Miyazaki, Y., A. Mahankali, M. Matsuda, S. Mahankali, J. Hardies, K. Cusi, L. J.Mandarino, and R. A. DeFronzo. 2002. Effect of pioglitazone on abdominal fat distribution and insulin sensitivity in type 2 diabetic patients. J. Clin. Endocrinol. Metab. 87:2784-2791.

Muurling, M., R. P. Mensink, H. Pijl, J. A. Romijn, L. M. Havekes, and P. J. Voshol. 2003. Rosiglitazone improves muscle insulin sensitivity, irrespective of increased triglyceride content in ob/ob mice. Metabolism 52:1078-1083.

Poulos, S., and G. Hausman. 2006. A comparison of thiazolidinedione-induced adipogenesis and myogenesis in stromal-vascular cells from subcutaneous adipose tissue or semitendinosus muscle of postnatal pigs. J. Anim. Sci. 84: 1076-1082.

Reginato, M. J., S. T. Bailey, S. L. Krakow, C. Minami, S. Ishii, H. Tanaka, and M. A. Lazar. 1998. A potent antidiabetic thiazolidinedione with unique peroxisome proliferatoractivated receptor $\gamma$-activating properties. J. Biol. Chem. 273: 32679-32684.

SAS Institute. 2004. User's Guide. Release 9.1 Edn. SAS institute Inc., Cary. NC..

Schwab, C., T. Baas, K. Stalder, and J. Mabry. 2006. Effect of long-term selection for increased leanness on meat and eating quality traits in Duroc swine. J. Anim. Sci. 84:1577-1583.

Singh, N., H. Chae, I. Hwang, Y. Yoo, C. Ahn, S. Lee, H. Lee, H. Park, and H. Chung. 2007. Transdifferentiation of porcine satellite cells to adipoblasts with ciglitizone. J. Anim. Sci. 85: 1126-1135.

Sisk, M. B., D. B. Hausman, R. J. Martin, and M. J. Azain. 2001. Dietary conjugated linoleic acid reduces adiposity in lean but not obese Zucker rats. J. Nutr. 131:1668-1674.

Souza, C. J., M. Eckhardt, K. Gagen, M. Dong, W. Chen, D. Laurent, and B. Burkey. F. 2001. Effects of pioglitazone on adipose tissue remodeling within the setting of obesity and insulin resistance. Diabetes 50:1863-1871.

Tan, B., Y. Yin, Z. Liu, X. Li, H. Xu, X. Kong, R. Huang, W.Tang,
I. Shinzato, and S. B. Smith. 2009. Dietary L-arginine supplementation increases muscle gain and reduces body fat mass in growing-finishing pigs. Amino Acids 37:169-175.

Tan, B., Y. Yin, Z. Liu, W. Tang, H. Xu, X. Kong, X. Li, K. Yao, W. $\mathrm{Gu}$, and S. B. Smith. 2011. Dietary L-arginine supplementation differentially regulates expression of lipid-metabolic genes in porcine adipose tissue and skeletal muscle. J. Nutr. Biochem. 22:441-445.

Tang, Z. R., L. Y. Yin, C. M. Nyachoti, R. L. Huang, T. J. Li, C. B. Yang, X. J. Yang, J. Gong, J. Peng, D. S. Qi, J. J. Xing, Z. H. Sun, and M. Z. Fan, 2005. Effect of dietary supplementation of chitosan and galacto-mannan- oligosaccharide on serum parameters and the insulin like growth factor-I mRNA expression in early-weaned piglets. Domest. Anim. Endocrin. 28:430-441.

Teboul, L., D. Gaillard, L. Staccini, H. Inadera, E. Z. Amri, and P. A. Grimaldi. 1995. Thiazolidinediones and fatty acids convert myogenic cells into adipose-like cells. J. Biol. Chem. 270: 28183-28187.

Todd, M. K., M. J. Watt, J. Le, A. L. Hevener, and L. P. Turcotte. 2007. Thiazolidinediones enhance skeletal muscle triacylglycerol synthesis while protecting against fatty acidinduced inflammation and insulin resistance. Am. J. PhysiolEndocrinol. Metab. 292:E485-E493.

Tontonoz, P., and B. M. Spiegelman. 2008. Fat and beyond: the diverse biology of PPAR $\gamma$. Annu. Rev. Biochem. 77:289-312.

Vasilijevic, A., L. Vojcic, I. Dinulovic, B. Buzadzic, A. Korac, V. Petrovic, A. Jankovic, and B. Korac. 2010. Expression pattern of thermogenesis-related factors in interscapular brown adipose tissue of alloxan-treated rats: Beneficial effect of 1arginine. Nitric Oxide 23:42-50.

West, D. B., J. P. Delany, P. M. Camet, F. Blohm, A. A. Truett, and J. Scimeca. 1998. Effects of conjugated linoleic acid on body fat and energy metabolism in the mouse. Am. J. Physiol-Regul. Intergr. Physiol. 275:R667-R672.

Wu, X., Y. L. Yin, T. J. Li, L. Wang, Z. Ruan, Z. Q. Liu, and Y. Q. Hou, 2010. Dietary protein, energy and arginine affect LAT1 expression in forebrain white matter differently. Animal 4: $1518-1521$

Wu, Z., N. Bucher, and S. R. Farmer. 1996. Induction of peroxisome proliferator-activated receptor gamma during the conversion of 3T3 fibroblasts into adipocytes is mediated by C/EBPbeta, C/EBPdelta, and glucocorticoids. Mol. Cell. Biol. 16:4128-4136.

Wu, Z., Y. Xie, R. F. Morrison, N. Bucher, and S. R. Farmer. 1998. PPARgamma induces the insulin-dependent glucose transporter GLUT4 in the absence of C/EBPalpha during the conversion of $3 \mathrm{~T} 3$ fibroblasts into adipocytes. J. Clin. Invest. 101:22-32.

Yang, C. B., D. M. Albin, Z. R. Wang, B. Stoll, D. Lackeyram, K. C. Swanson, Y. L. Yin, K. A. Tappenden, Y. Mine, R. Y. Yada, D. G. Burrin, and M. Z. Fan. 2011. Apical Na+-D-glucose cotransporter 1 (SGLT1) activity and protein abundance are expressed along the jejunal crypt-villus axis in the neonatal pig Am. J. Physiol. Gastrointest. Liver Physiol. 300:G60-G70.

Yang, C. B., A. K. Li, Y. L. Yin, R. L. Huang, T. J. Li, L. L. Li, Y. P. Liao, Z. Y. Deng, J. Zhang, B. Wang, Y. G. Zhang, X. J. Yang, J. Peng, and M. Z. Fan. 2005. Effects of dietary supplementation of cysteamine on growth performance, 
carcass quality, serum hormones and gastric ulcer in finishing pigs. J. Sci. Food. Agric. 85:1947-1952.

Yao, K., L. Y. L. Yin, X. L. Li, P. B. Xi, J. J. Wang, J. Lei, Y. Q. Hou, and G. Y. Wu. 2012. Alpha-ketoglutarate inhibits glutamine degradation and enhances protein synthesis in intestinal porcine epithelial cells. Amino Acids 42:2491-2500.
Yin, F. G., Z. Z. Zhang, J. Huang, and Y. L. Yin. 2010. Digestion rate of dietary starch affects systemic circulation of amino acids in weaned pigs. Br. J. Nutr. 103:1404-1412.

Yin, Y. L., S. K. Baidoo, J. L. L. Boychul, and H. H. Simmins. 2001. Performance and carcass characteristics of pigs and broiler fed diets containing micronized barley, ground barley, wheat and maize. J. Sci. Food. Agric. 81:1487-1497. 